\title{
A theology of marriage: A biblical or a cultural construct?
}

\begin{tabular}{|c|c|}
\hline \multicolumn{2}{|c|}{$\begin{array}{l}\text { Author: } \\
\text { Ernest van Eck }{ }^{1} \bullet\end{array}$} \\
\hline \multicolumn{2}{|c|}{ 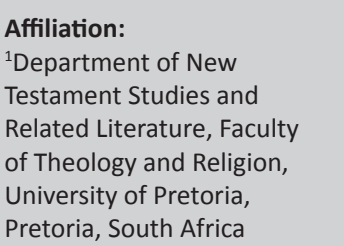 } \\
\hline \multicolumn{2}{|c|}{$\begin{array}{l}\text { Research Project } \\
\text { Registration: } \\
\text { Project Leader: E. van Eck } \\
\text { Project Number: } 2400030\end{array}$} \\
\hline \multicolumn{2}{|c|}{$\begin{array}{l}\text { Description: } \\
\text { This research is part of the } \\
\text { project 'Hermeneutics and } \\
\text { Exegesis' directed by Prof. Dr } \\
\text { Ernest van Eck, Department } \\
\text { of New Testament and } \\
\text { Related Literature, Faculty of } \\
\text { Theology and Religion, } \\
\text { University of Pretoria. }\end{array}$} \\
\hline \multicolumn{2}{|c|}{$\begin{array}{l}\text { Corresponding author: } \\
\text { Ernest van Eck, } \\
\text { ernest.vaneck@up.ac.za }\end{array}$} \\
\hline $\begin{array}{l}\text { Dates: } \\
\text { Received: } 07 \mathrm{~A} \\
\text { Accepted: } 24 \\
\text { Published: } 04\end{array}$ & $\begin{array}{l}\text { Apr. } 2020 \\
\text { Aug. } 2020 \\
\text { Dec. } 2020\end{array}$ \\
\hline \multicolumn{2}{|c|}{$\begin{array}{l}\text { How to cite this article: } \\
\text { Van Eck, E., 2020, 'A theology } \\
\text { of marriage: A biblical or a } \\
\text { cultural construct?', HTS } \\
\text { Teologiese Studies/ } \\
\text { Theological Studies } 76(4), \\
\text { a6027. https://doi.org/ } \\
\text { 10.4102/hts.v76i4.6027 }\end{array}$} \\
\hline \multicolumn{2}{|c|}{$\begin{array}{l}\text { Copyright: } \\
\text { (c) 2020. The Authors. } \\
\text { Licensee: AOSIS. This } \\
\text { is licensed under the } \\
\text { Creative Commons } \\
\text { Attribution License. }\end{array}$} \\
\hline \multicolumn{2}{|l|}{ Read online: } \\
\hline 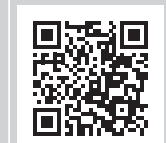 & $\begin{array}{l}\text { Scan this QR } \\
\text { code with your } \\
\text { smart phone or } \\
\text { mobile device } \\
\text { to read online. }\end{array}$ \\
\hline
\end{tabular}

This article argues that the contemporary mainline understanding of marriage (theology of marriage), especially in the local South African denominational context, is not 'based on the Bible', but rather on a cultural construct. Moreover, this construct is not based on JudeoChristian values and norms; it is the result of early Christianity's enculturation into the world of the Roman Empire. It is also argued that a definition of Christian marriage as being an institution originated by God, consisting of a monogamous and lifelong relationship between a man and a woman, cannot be based on the Bible. The reason for this is that the institution of marriage in ancient times was something totally different from what we understand today, the fact that the Bible also gives evidence of different understandings (forms) of marriage from the time of the patriarchs up to the 2nd century, and that Jesus, Paul and the Church Fathers preferred celibacy to marriage.

Contribution: This article aim to contribute to the current discussion, especially in the local South African denominational context, on the institution of marriage as being 'biblical', and its relationship to same sex-relations being typified as marriages.

Keywords: marriage; Christian marriage; Jesus; Paul; celibacy; Augustus; cultural construct; biblical, Church Fathers.

\section{Introduction}

The majority of church denominations in South Africa are unanimous in their views on marriage: marriage is an institution originated by God and consists of a monogamous and lifelong relationship between a man and a woman. The Apostolic Faith Mission (AFM), for example, defines the institution of marriage as a 'sacred institution originated by God ... a covenant relationship which establishes a bond between a man and a woman that is dissolved only when death causes the inevitable separation'. ${ }^{1}$ As scriptural support for this definition of marriage, Matthew 19:4-6 and Mark 10:5-9 are listed, clearly implying that this understanding of marriage as an institution is biblical (i.e. based on Scripture). The New Apostolic Church (NAC) defines the institution of marriage in the same manner: marriage is a divine institution consisting of a lifelong monogamous relationship between a man and a woman. To underscore the importance and value of marriage as a divine institution, the website of the NAC continues by stating that 'God has explicitly anchored the protection of marriage within the Ten Commandments'. To indicate that their understanding of marriage is based on the Bible, Genesis 1:27-28, 2:18 and 2:24 are listed. ${ }^{2}$ The Uniting Presbyterian Church in Southern Africa (UPCSA), in a statement on marriage in 2016, reiterated their point of view as adopted by the Executive Commission in 2005 and confirmed by the General Assembly in 2006:

$[M]$ arriage $\ldots$ is an ordained covenant that exists between one man and one woman under God for life, and holds this definition to be consistent with the authoritative rule of Scripture as well as the tradition of the one, holy, catholic and apostolic Church. ${ }^{3}$

Thus, again, more or less the same definition, or less the same definition as the definitions given above, and again an understanding of marriage based on the Bible. The same understanding of marriage is held by the Methodist Church of Southern Africa. In The Methodist Book of Order: The 1.See entry 'The sanctity of marriage', at http:///apostolicfaith.org/online-magazine/77272751147854339thesanctityofmarriage.

2.See entry 'Marriage as a divine institution', at http://www.nak.org/catechism/13-new-apostolic-christians-and-their-life-of-faith/133marriage-and-family/1331-marriage-as-a-divine-institution/.

3.See entry http://unitingpresbyterian.org/web/wp-content/uploads/2013/09/statement_on_marriage.pdf. 
Laws and Discipline of the Methodist Church of Southern Africa, the norm for marriage is described as a relationship between one man and one woman (see Methodist Church of Southern Africa 2016:226, 228.)

Turning to the three Afrikaans-speaking churches in South Africa, the Netherdutch Reformed Church in Africa (NRCA), during its 2019 General Assembly, adopted a new formula for the confirmation of marriage, which states that marriage as an institution is a 'spiritual and physical unity between man and woman', 'founded upon the principles found in the Word of God' (NHKA 2019:48). ${ }^{3}$ Thus, again, an understanding of marriage is based on the Bible. The Reformed Churches in South Africa, in their turn, see marriage as a holy communion in Christ between a man and a woman of the same faith. Marriage as an institution was instituted by God, as attested in the Holy Scripture (see GKSA 2015:78, 79).

The Dutch Reformed Church (DRC), in its understanding of marriage, admits that the institution of marriage, as understood today, is the product of a long developing tradition. Part of this developing tradition, for example, are levirate marriage and the wife being the property of the husband - aspects of the developing tradition that no longer can be considered as part of how a 'Christian marriage' should look like today (NGK 2015:190). The DRC, however, believes that the historical development of the institution of marriage as described in the Bible gives clear enough guidelines to conclude that a Christian marriage 'is a permanent and formal relationship between two people from the different sexes aiming to share their lives with one another for as long as they live' (DRC 2015:190; my translation from the Afrikaans). This relationship, according to the NRC, is a 'gift of God' (Nederduitse Gereformeerde Kerk 2015:191), 'based on the Bible' (DRC 2015:187), and, because it was 'instituted by God' (DRC 2015:15), a 'gift from God' (DRC 2015:188; my translation from the Afrikaans). ${ }^{4}$

From the above discussion, it can be concluded that marriage is an institution originated by God, consisting of a monogamous and permanent relationship between one man and one woman, an understanding of marriage based on the authority of and principles in the Bible. This article questions the premise that the above understanding of marriage is 'based on the Bible'. Focusing on (1) the difference between the institution of marriage as understood in biblical times and today; (2) the different forms of marriage (marriage strategies) found in the Bible; (3) the preference of celibacy as advocated by Jesus, Paul and the Church Fathers; and (4) the influence of Graeco-Roman (Augustan) laws on the

3.In their church order (Kerkorde), the NHKA (see 2016:75) describes their understanding of the institution as a 'Christian' marriage. In essence, 'Christian' and 'Biblical' are seen as the same thing.

4.As a result of a decision taken by the DRC during its General Synod in 2019 on samesex relationships and the ordination of homosexual persons into the ministry, a sex relor number of congregations convened on 25 and 26 March 2020 at the Moreletapar congregation in Pretoria to $w$ not. During the 2 day deliberations, an emeritus minister of the DRC, Rev. Johan (Tokkie) Ernst, stated that 'marriage, according to the Bible, consists of only a man and a woman', 'we explicitly believe in marriage between a man and a woman', an understanding of marriage is 'based on the Bible' (see Janse van Rensburg 2020). understanding of marriage by Christians at the end of the 1st century and the beginning of the 2nd century, this article argues that the current 'stock' understanding of marriage (theology of marriage) is not based on 'the Bible', but rather on a cultural construct shaped by a variety of factors and influences. Above all, it will be indicated that the roots of our current understanding of marriage owe more to Roman Imperial beliefs than the assumption that our understanding is based on Judeo-Christian norms and values.

\section{Marriage as an institution: Then and now ${ }^{5}$}

The view that the Bible prescribes that the institution of marriage should consist of a monogamous and lifelong relationship between a man and a woman has no support from the texts of the Bible itself. To the contrary, the understanding of what marriage entailed in the period covered by the Old Testament and New Testament indicates almost no parallel with our modern 'Biblical' understanding of the institution of marriage.

Marriage, or the different kinds of marriages (see below) we encounter in the Old Testament and New Testament, is the product(s) of the dominant cultural scripts of the Eastern Mediterranean, the social system in which the biblical texts originated. ${ }^{6}$ Marriages therefore were parentally arranged and made by extended families. In essence, two families got married with a view to political and economic concern. One family offered a male, the other a female, and the wedding symbolised the fusion of the honour of the two extended families involved. Individuals did not get married; families did (see Countryman 1988:158; Malina \& Rohrbaugh 2003:28, $240)$. In terms of the pivotal value of honour, marriage was the process of disembedding the prospective wife from the honour of her father and embedding her in the honour of her husband-to-be (Osiek 2006:833).

The initial phase of this process consisted of a period of betrothal, ${ }^{7}$ and the process ended with the wedding proper. Marriages always were political, economic, religious and kinship arrangements, and therefore often arranged long before the wedding proper; betrothal thus extended over a considerable length of time (Malina \& Rohrbaugh 2003:241). Women were normally betrothed before the age of puberty (Instone-Brewer 2002:117), and after betrothal became the property of the husband-to-be. After the marriage proper, a

5.For a detailed description of marriage during the time of the Old Testament and New Testament, see Van Eck (2007a:103-128). Because of limited space, only a selection of works used in this description are cited here.

6.The dominant cultural scripts of the Eastern Mediterranean social system that influenced the institution of marriage in the Old Testament and New Testament are honour and shame (Malina 1981:27-28; Malina \& Neyrey 1991:41-41; Malina \& Rohrbaugh 2003:213; Neyrey 2004:261), dyadic personality (Malina 1981:94; Neyrey 1993a:49-52, 1993b:88-91; Van Eck 1995:176) and marriage embedded in the social institution of the family (Malina 1981:94-95; Malina \& Rohrbaugh 2003:28, 30, 241)

7.Betrothal is the period during which the prospective spouses were set apart from each other; they were betrothed that is, prospective spouses were set apart from apart means in the Hebrew' (see Malina \& Rohrbaugh 2003:241). A couple betrothed did not live together, although a formal divorce was required to break the betrothed did not live together, although a formal divorce was required to break the woman was considered as adultery, that is, taking the property of a male. 
wife remained for most part on the periphery of her new husband's family, and was perceived as a 'stranger' or outsider (Malina \& Rohrbaugh 2003:241).

Being the property of the husband, adultery purely referred to taking someone else's property by means of sexual intercourse. ${ }^{8}$ As a female (wife) had no honour standing, a husband could only commit adultery (steal the property) against another male (the husband); no adultery was committed against the wife. Divorce, finally, entailed the dissolution of the agreement between the two families that was agreed upon when the marriage was arranged (Malina \& Rohrbaugh 2003:95). ${ }^{9}$

From the above discussion, it is clear enough that what we nowadays see as our marriages being 'biblical' actually has very little to no footing in the Bible. The difference between how we define marriage and the way it was practised in Old Testament and New Testaments becomes even more explicit when we consider the different marriage strategies and marriage norms we encounter in the texts of the Bible. We now turn to that aspect.

\section{Marriage strategies in the Bible ${ }^{10}$}

Malina (1981:129-143) identifies five marriage strategies ${ }^{11}$ in the texts of the Bible: three in the Old Testament and two in the New Testament. In the Old Testament - if one accepts the broad periods of the history of Israel as the patriarchal immigrant period, the Israelite pre-exilic period and Israelite post-exilic period - the marriage strategies, respectively, were conciliatory, aggressive and defensive, with endogamy constantly as the ideal. ${ }^{12}$ In the patriarchal immigrant period, Abraham and his 'offspring' enshrined the endogamous ideal (Abraham, e.g., married his half-sister); marriage was patrilocal; the patriarchs readily offered their wives (and daughters) for political protection, economic advantage or higher status (also known as sexual hospitality); and polygamy was an accepted norm (Malina 1981:129-131). In the Israelite pre-exilic period, the strategy was aggressive, as can be seen from the actions of Simeon and Levi in the story of Shechem (Gn 34): sexual hospitality was a thing of the

8.'Adultery referred purely and simply to a man's having intercourse with a married woman ... it is usurping some other man's property rights in his wife ... a property violation' (Countryman 1988:156-158). See also Vardy (2009:187): 'Adultery is clearly ... seen as a violation of property rights'.

9.Apart from being different from what we as moderns understand the concept of divorce, the New Testament for example, is not clear on the legal grounds for divorce. According to Luke 16:18, a husband who divorces his wife and marries another woman commits adultery. Matthew 19:9 argues the same, except for cases where sexual immorality is involved. Mark 10:11-12 follows Luke 16:18, but also makes it possible for a wife to divorce her husband. Even if one wants to interpret
these texts anachronistically, it clearly contains conflicting points of view on who may initiate a divorce and on what grounds it will be acceptable.

10.For a detailed description of the different marriage strategies encountered in the Old Testament and New Testament, see Van Eck (2007b:91-100). The summary below is taken from Malina (1981:129-143), and only the essentials of each strategy are mentioned.

11.By marriage strategy, Malina (1981:130) specifically means 'behavior based on the perception of how the female is embedded in the male's honor'.

12.Endogamy entails the preference for keeping daughters close to the nuclear family, that is, the requirement that a spouse must come from within the kinship unit. Endogamy prohibits marriages outside the kinship group and implies a closedness to outside groups, and symbols particularism, because it results in a society of relatively small, closed segments (Malina 1981:119) past; wives and sisters were perceived as embedded in their honour of the patriarchal male; daughters of the patriarchal married relatives as close to home as incest laws allowed; and sons married non-relatives and brought the spouse into the patrilocal community. As an expression of the agonistic quality of social relations typical of Mediterranean communities in antiquity, the patriarchal male thus gained sons-in-law, daughters-in-law and a range of offspring. The strategy in this period was all about gaining numbers and political power, enabling the patriarch to acquire even more women. Obviously, polygamy was at the order of the day (Malina 1981:131-134). The marriage strategy of the next period, the Israelite post-exilic period, overturned the strategy and many of the value and norms of the previous period. The experience of the period of exile and subsequent return marked a change in the central symbols of Israel, and hence in marriage strategy also. Based on an ideology of a holy people, holy land and holy seed (offspring), the marriage strategy now was defensive. The holiness code (purity code) of the Priestly tradition set explicitly formulated social lines that marked 'us' (Israelites) from 'them' (the rest of humankind). Based on the holiness code, the reforms of Ezra and Nehemiah required the divorce of all non-Israelite wives (and their children) acquired by the returning exiles from native non-Israelite families, along with marriage to fellow Israelites only. As a result of this new marriage strategy, more stringent incest lines prohibited degrees of marriage; adultery, sexual hospitality, homosex, keeping Israelite women as slave-wives, and priestly marriages with onceembedded or shamed women were considered as abominations before the Lord. Marriage was still patrilocal, and monogamy now was the ideal, but not always practised (see Malina 1981:134-138).

The two final marriage strategies are that of the churches of Paul (the Pauline interval with a charismatic defensive strategy) and the churches after Paul (the post-Pauline period with a Christian defensive strategy (Malina 1981:138-142). In Paul's letters, the Pauline interval, we find a continuation of the defensive strategy, but with a twist. Although for Paul celibacy was the best option (see below), his advice is that Christians should stay in the marriages they had when they became Christian, but if the unbelieving partner causes difficulty, peace is of greater value than preserving the marriage. Regarding new marriages and remarriages, these should take place between fellow Christians. In essence, 'Israel' is replaced by 'Christian', a holy group (the church of the saints) headed by charismatic leaders, with the marriage strategy still being defensive. In the post-Pauline period, Christian custom becomes Christian law, with sanctions deriving from the Christian church. Men should marry women born within the Christian church or those who entered the group in an unmarried state, and marriages with outsiders are to be avoided. This is a defensive Christian marriage strategy, motivated by and based on new Christian norms such as those found in Ephesians 5:22-33, Colossians 3:18-25, 1 Peter 2:11-3:12, 1 Timothy 2:8-15; 4:1-5 and 1 Timothy 5:3-16. These norms, interestingly, did not exclude 
polygamy, as can be seen from 1 Timothy 3:2 and Titus 1:6 where it is expected that from someone who wants to become

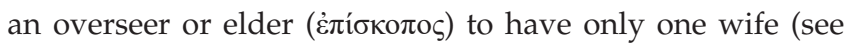

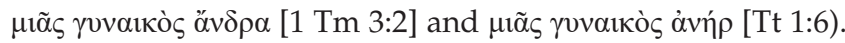
The same was expected from deacons, in that they also had to

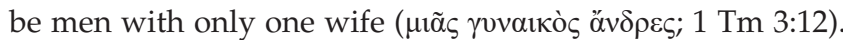
Clearly, this implies that for other men in the congregation polygamy was in order, but not for elders and deacons (see also Wheeler-Reed 2017:79). ${ }^{13}$

From the above discussion, two remarks should be made. Firstly, if one argues that Genesis 1:27-28 (marriage consisting of a male and a female) and Genesis 2:24 (a man should leave his father and mother) are evidence of God ordaining marriage as an institution, as it is so often done, what to make of the patrilocal and polygamous characteristics of the different forms of marriages described above? Which one of the five different forms did God ordain? Secondly, the way in which most churches define marriage parallels that of the form of marriage practised in the post-Pauline period. This understanding of marriage was based on Christian customs, cultural customs that soon took on 'the quality of law, administered by duly chosen officers' (Malina 1981:142). Is this not also the case with many denominations' current understanding and definition of marriage? Our definition of marriage is not 'biblical', but rather based on a constructed 'theology of marriage'. This 'theology of marriage' is, moreover, not only based on very specific cultural conventions, but also includes the 'overriding' of specific cultural values and norms because of a new cultural environment. To name but one example, Ephesians 5:22-23 explicitly states that the husband is the head of the wife, and that wives should submit themselves to their husbands. In a postmodern world of human rights and the movement towards the equality of the sexes - read cultural convictions - this is deemed as biblical instructions not applicable anymore. As such, our understanding of marriage is much more a cultural construct than 'biblical'. In the next section, more will be said on the institution of marriage as a cultural construct; however, firstly, we turn to yet another aspect that seriously complicates our 'biblical' understanding of marriage, that is, Jesus and Paul's preference for celibacy and not marriage.

\section{Marriage or celibacy? Jesus, Paul and the early church}

A matter that further complicates the 'biblical' understanding of marriage (a lifelong monogamous relationship between one man and one woman as ordained by God) is Jesus, Paul and some of the Church Fathers' preference for celibacy, not marriage. For them (including, e.g., John the Baptist), being Jewish men, it would have been 'normal' to get married. Both of them, however, had an idiosyncratic preference for celibacy (Loader 2005:183; see also Loader 2012:447-453). ${ }^{14}$ Put bluntly, in terms of the view of Jesus and Paul, the 'biblical' understanding of marriage would mean not to get married at all.

13.Early Jewish writings and Josephus (Ant. 17:14) refer to polygamy as an acceptable practice, as confirmed by Justin (Dial. 141) in 180 CE.

14.Also see Brownson (2013:126-147), Deming (2004:210-214), Duff (2017:154-161), Hunter (ed. 2018:3-7), Köstenberger (2003:264-267) and Loader (2005:149-192, 2012:152-239, 2013:100-104) for a discussion of Jesus and Paul on celibacy.
Jesus' choice for celibacy is clear form Matthew 19:12 (emphasis added):

[F]or there are eunuchs who were born that way, and there are eunuchs who have been made eunuchs by others - and there are those who choose to live like eunuchs for the sake of the kingdom of heaven. (Mt 19:12; NIV)

Loader (2005) comments on this Jesus-logion as follows:

$[T]$ he threefold saying uses eunuch as an image. It is striking because it is using a category that is unclean. This means it coheres well with other shocking sayings of Jesus. (pp. 131-132)

The first two realities 'prepare for a third which Jesus introduces: some have made them eunuchs for the kingdom of heaven; they have chosen to be celibate' (see also Loader 2013:102). Similarly, in Luke 18:29-30,15 Jesus models his own ministry in such a way that it 'displaces the normal responsibilities of marriage and family, commending this way of life to at least some of his followers as well' (Brownson 2013:129).

Linked to these two sayings of Jesus, many other of his sayings have an explicit anti-familial slant. These sayings include, inter alia, the following Jesus-logia:

- Gospel of Thomas 55:1-2, 101:1, and Q 14:26-27 (Lk 14:26-27 / / Mt 10:37-38): following Jesus implicates hate for one's family (see also Mk 1:16-20 and par.; Mk 10:29-30 and par.; Mk 8:34 and par.; Mk 6:1-6 and par.).

- Gospel of Thomas 99:1-3 and Mark 3:32-35 and par.; Jesus's family is not his biological family but those who do the will of the Father.

- Gospel of Thomas 16:1-4, and Q 12:51 (Lk 12:51-53; Mt 10:34-36): Jesus did not come to bring peace, but the sword (see also Gos. Thom. 49:1; 75).

- Gospel of Thomas 86, and Q 9:57-60 (Lk 9:57-60; Mt 8:18-22): Jesus has no place to stay, and those who want to follow him have no time to first bury their fathers). ${ }^{16}$

Several scholars argue that the reason for Jesus' anti-familial stance most probably was the androcentric, patriarchal and hierarchical characteristics of the institution of the family he encountered in his day. ${ }^{17}$ The family, as versed by Kloppenborg (1990:196), was 'the basis for the dehumanization of women, children and non-dominant males'. Because of this, Jesus opted for celibacy, not willing to be part of an institution that dehumanised and marginalised women, children and non-dominant men.

15.'Truly I tell you', Jesus said to them, 'no one who has left home or wife or brothers or sisters or parents or children for the sake of the kingdom of God will fail to receive many times as much in this age, and in the age to come eternal life (Lk 18:29-30; NIV).

16.For a detailed discussion of the anti-familial content of these texts, see Van Eck (2007c:481-513; Duff 2017:140-144; see also Köstenberger 2003:244-247).

17.For a discussion on the androcentric, patriarchal and hierarchical characteristics of the familial institution in the 1st-century Roman-Palestine, see Countryman (1988:168-173, 18) Crossan (1991:299-301). Horsley (1993.231-245) Loader (1988:168-173, 18), Crossan (1991:299-301), Horsley (1993:231-245), Loade (2004:205), Meier (1991:316-317), Osiek (2006:838-842), Pilch (1993:101-113) and Schüssler Fiorenza (1982:151-154). Loader (2005:205), for example, states the following: 'Jesus' radical sayings about family are more subversive than is usually recognized ... it is a challenge to the household system which underpinned social structure in the ancient world as basis for the systems of control, economy, production and patronage'. 
Like Jesus, Paul states his preference for celibacy when he addresses the slogan of some of the members of the believing community in Corinthians, 'It is good for a man not to have sexual relations with a woman' (1 Cor 7:1; NIV). In commenting on this slogan, Paul is of the opinion that the practice of marriage can still be accommodated as is not wrong (1 Cor 7:28, 36), but it the second best option and should be seen as a concession. ${ }^{18}$ For Paul, it seems that marriage is a way of avoiding the dangers of sexual immorality, and a remedy for a lack of self-control (1 Cor $7: 2 a$, 5b $925,36-37)$. While in marriage, sexual relations should not be avoided for extended periods (1 Cor 7:3-7), and divorce must be avoided as far as possible (1 Cor 7:10-13). The best, however, is to remain single (1 Cor 7:8, 26-27), even after divorce (see Loader 2005:183). Loader (2005:185) correctly states that this choice of Paul is not, contrary to common belief, solely or primarily based on his belief in imminent eschatology. The grounds for his belief also include the tension between time for sexual relations and prayer (1 Cor 7:5), present hardships (1 Cor 7:26, 28b), that the world is transitory and therefore time is short (1 Cor 7:31), marriage as distraction to serve the Lord (1 Cor 7:32-35) and that in the age to come all things will cease to exist (1 Cor 7:17-35).

For different reasons then, Jesus and Paul preferred celibacy to marriage, and based on this preference, no such thing as a 'biblical marriage' can be imagined. This was also the point of view of some of the Church Fathers. Early on, only a few of the Church Fathers made passing comments on marriage. Clement of Rome (96 CE), in 1 Clement 33:4-8 [Ehrman, LCL], and Ignatius (35-140 CE; see Ign. Pol. 5:1-2 [Ehrman, LCL]), for example, affirmed the goodness of marriage, and described celibate Christians as arrogant (ed. Hunter 2018:15). Marcion (ca. 85-160 CE), Valentinus (ca. 100-160 CE) and Tatian (110-180 CE), also known as the Encratites (the 'abstainers' or 'self-controlled'), denied the right to marriage (see ed. Hunter 2018:18). Being a Gnostic, Marcion believed that human sexual activity was something 'to be transcended and repudiated' (ed. Hunter 2018:18), while Valentinus, also a Gnostic Christian, considered 'ordinary marriage' to be defiled and 'spiritual marriage' (celibacy) as the ideal (DeConick 2003:308). According to Tatian (110-180 CE), Paul linked sexual activity to uncontrolled, Satanic fornication, and that only by renouncing all sexual activity people could be restored to their original spiritual condition intended by God before the Fall. The Encratites' preference for celibacy was contended by Irenaeus (130-202 CE; see Hear. 1.28.1; 4.11.1 $)^{19}$ and Tertullian (155-220 CE; see Marc. 1.29.1-9), ${ }^{20}$ but by the end of the 3rd century, it appears that within Christianity, celibacy was seen as superior to marriage,

18.Wheeler-Reed (2017:66-67) interestingly mentions that in all of his letters, Paul only twice mentioned two parents and their children (Rm 16:13; 1 Cor 5:1-5), indicating a lack of interest in children. This, Wheeler-Reed argues, also supports Paul's preference for celibacy.

19.In Adversus haereses 1.28, Irenaeus calls the Encratites' preaching against marriage a heresy that sets aside the original creation of God, and in Adversus haereses 4.11.1 states that God created man to grow and multiply, citing Genesis 1:28 (see https://www.newadvent.org/fathers/0103.htm).

20.In his Adversus Marcionem 1.29.1-9, Tertullian argues that marriage is not to be refused because, when enjoyed without moderation, it is like a voluptuous refused because, when enjoyed without moderation, it is like a voluptuous
flame and not evil, as Marcion is arguing (see https://www.newadvent.org/ fathers/0312.htm) although marriage was allowed. Typical of this period were the works of Methodius of Olympus (250-311 CE) and Lactantius (240-320 CE); both were of the opinion that marriage was valid, but that celibacy was the higher way of life (see ed. Hunter 2018:15-21; Wheeler-Reed 2017:88-91). A further aspect that strengthened this point of view was, also towards the end of the 3rd century, the emergence of 'solitaries' or 'monks'. Monasteries soon appeared, in which ascetism and sexual restraint were seen as a higher morality (ed. Hunter 2018:24).

Thus, from the beginning of the 2nd century to the end of the 4th century, the point of view (Martin 2006):

$[W]$ hich valued celibacy over marriage, gradually became the more dominant position in late ancient Christianity, at least among the church's leaders ... By the late fourth century, it was difficult to find a church leader with a different opinion. (p. 116)

Marriage was seen 'on the most favorable interpretation, as a poor second best' (Kelly 1998:102).

\section{Marriage as a social product and cultural construct}

The Deutero- and Trito-Pauline letters, most probably written between 80 and $130 \mathrm{CE}$, interestingly give no evidence of the marriage vis-à-vis celibacy debate in earliest Christianity. In these letters, marriage has won the day. Jesus' preference for celibacy and anti-familial stance has faded into the past. The same goes for Paul's preference for celibacy, based on inter alia on his belief in imminent eschatology. This can especially be seen in these letters' deafening silence on eschatology, and the normalcy of household codes and other texts referring to family matters and relationships with the family, implicitly replacing any anti-familial ideas (see, e.g., Eph 5:22-33; Col 3:18-25; 1 Tm 2:8-15, 4:1-5, 5:3-16; Tt 1:6, 11).

Contrary to Jesus and Paul, for these letters, marriage is the norm, and some even warn against the 'false teaching' on celibacy. With regard to the latter, 1 Timothy 4:2-3 warns against the 'hypocritical liars', who 'forbid people to marry and order them to abstain from certain foods'. This is at least an implicit reference to the Encratites who forbade marriage and counselled abstinence from meat and wine. Hebrews 13:4, likewise, urges that marriage should be held in honour by all, 'suggesting perhaps that some early Christian circles may have looked on marriage with some suspicion - or even disdain' (Brownson 2013:129). 1 Timothy 5:14 and 1 Timothy 3:2, on the other hand, see marriage as the expected norm: young widows should remarry, and he who wants to be an elder must have only one wife and manage his household well. This is also the case in the Deutero-Pauline letters: the husband is the head of the wife, and wives should submit themselves to their husbands (Eph 5:22-23; Col 3:18), husbands must love their wives (Eph 5:33; Col 3:19), wives must respect their husbands (Col 3:18) and children should obey their parents in everything (Col 3:20). Clearly, marriage was the norm.

Why this clear preference for marriage? According to Duff (2017:150-152), directly after the resurrection, the brothers 
(especially James) and mother of Jesus became influential in earliest Christianity. The family of origin thus replaced the 'family' of Jesus, and therefore marriage replaced celibacy. Secondly, the early mission of the followers of Jesus was directed at families, and the earliest Christian believing communities consisted of extended families. Family networks were important for the growth of the movement, especially when the movement reached the Hellenised cities of the eastern empire (Duff 2017:152). The most important reason, however, was enculturation. As the movement grew in numbers, places and influence, survival meant a kind of conformity (Wheeler-Reed 2017:78) to cultural forces. Thus, by the end of the 1st century (Duff 2017):

$[A] \mathrm{s}$ Christianity struggled to move into the mainstream of Greco-Roman society, opinions in the movement began to change. While Paul (and Jesus) favoured celibacy (the Deuteroand Trito-Pauline letters) disparaged it. (p. 158)

Very soon, the Graeco-Roman understanding of family, its patriarchal ideology and understanding of household was part of the Christian movement. In short, the Christian household became the Graeco-Roman household, 'the traditional roles and structures of the Roman household were now regarded as normative for the church' (ed. Hunter 2018:7), and marriage now was central to being a Christian. As poignantly put by Wheeler-Reed (2017:80): 'Augustus would have approved'.

Around the beginning of earliest Christianity, Augustus issued a series of laws relating to marriage and procreation. The first was the Lex Iulia et Papia Poppaea (8 CE), which made it law for all men between 25 and 60 years of age and all Roman women between 20 and 50 years to marry. Divorcees and widows between 20 and 60 years of age were to remarry, and univira (married to only one person for life) became the ideal. Linked to this law was the Lex Iulia de maritandis ordinibus (18 CE), which inter alia set an expectation on production for men and women, respectively, at the age of 25 and 20, gave special privileges to married couples who had multiple children, and put taxes on unmarried women. The Lex Iulia de adulteriis coercendis, as a final example, aimed to repress forms of non-marital sex, particularly adultery considered to be unacceptable by Roman society (see Field 1945:398-416; Severy-Hoven 2012a, 2012b; Wheeler-Reed 2017:4-14).

It is not difficult to see the parallels between the Augustan laws and what we find in the Deutero- and Trito-Pauline letters. In the beginning of the 2nd century, with its mission aimed at households, in a Hellenised Roman Empire, Christians, to survive, prosper and accepted as movement, had to adapt to its cultural environments. As put by Wheeler-Reed (2017):

$[W]$ ithin twenty-five to fifty years, the ethics of second- and third-generation Christians begin to appear much more compatible with the tenets of Augustan marriage laws. For the sake of survival, early Christians redefine their family ideologies as they socialize themselves into the world of the Roman Empire. ${ }^{21}$ (pp. 84-85)

21.The assimilation of Christians into the broader culture of the Roman Empire can also be seen in texts like 1 Timothy 2:1-2 and 1 Peter 2:17 that admonish Christians to pray for kings and all those in authority in order that the rulers live peacefully

\section{Conclusion}

The understanding of many contemporary Christians and denominations of marriage as an institution originated by God, consisting of a monogamous and lifelong relationship between a man and a woman, is not based on the Bible. Not only was the institution of marriage in ancient times totally different from what we understand marriage as an institution today, but the Bible also gives evidence of different understandings (forms) of marriage from the time of the patriarchs up to the 2nd century. Jesus and Paul preferred celibacy, not marriage, and the Church Fathers considered marriage only as the 'second best' option to celibacy. For them, celibacy was 'biblical'.

The contemporary mainline understanding of marriage, especially in the local South African denominational context, is based on the Deutero- and Trito-Pauline letters (literary products of the post-Pauline period) in which the understanding marriage and 'family values' are the product of enculturation into the world of the Roman Empire. As such, the contemporary understanding of marriage is based more on Roman Imperial beliefs than on the assumption that our understanding is based on Judeo-Christian norms and values (Wheeler-Reed 2017:xxi). The basis for our current understanding of marriage is therefore more cultural than 'biblical'. In the words of Rohrbaugh (2006, emphasis added):

[W]e often claim the canon to be the rule for faith and practice in the Christian community and yet we demonstrate by the way we read the Bible that our commitment to culture has been far more profound than we are willing to admit. Culture, not canon, has too often shaped the life of the Church. (p. 574)

One final remark is that literary evidence indicates that the marriage laws of Augustus were not always popular, because it was general knowledge that for Augustus it was not about family morals and values, but a stimulation of the birth rate to strengthen the empire's military manpower (Wheeler-Reed 2017:xxi, 4). In Marxist terms, Augustus created a false conception of reality, that is, establishing values and morals, fuelled by the 'false consciousness' of the birth of soldiers. Wheeler-Reed (2017:xxi) argues that the modern Christian ideologies of marriage, especially in the United States of America, are not Judeo-Christian but are fuelled by the 'false consciousness' known as capitalism. In the local South African denominational context, the ideology of marriage also created a false conception of reality: marriage is presented as 'biblical' as long as it is understood as an institution originated by God, consisting of a monogamous and lifelong relationship between a man and a woman. It is, however, fuelled by a 'false consciousness' that wants to control sexual behaviour. This becomes clear, time and again, when samesex relations are discussed; sexual activity is only accepted

and quietly in all godliness and holiness, and that the emperor should be honoured (see Wheeler-Reed 2017:84) 
and 'holy' when it is practised by two heterosexual persons within wedlock.

The form of marriage (strategy), through the ages, was always influenced by a variety of historical, social and cultural factors. Moreover, the form marriage took always served as a means to an end. And it is still the case today, especially when it is used to label same-sex relations as sinful and unacceptable. Interestingly, in this case, that what is not 'biblical' (marriage) is used in an unbiblical manner, a manner that did not originate with the historical Jesus.

\section{Acknowledgements Competing interests}

The author declares that he has no financial or personal relationships that may have inappropriately influenced him in writing this article.

\section{Author's contribution}

The author has declared that he is the sole author of this research article.

\section{Ethical consideration}

This article followed all ethical standards for a research without direct contact with human or animal subjects.

\section{Funding information}

This research received no specific grant from any funding agency in the public, commercial or not-for-profit sectors.

\section{Data availability statement}

Data sharing is not applicable to this article as no new data were created or analysed in this study.

\section{Disclaimer}

The views and opinions expressed in this article are those of the author and do not necessarily reflect the official policy of any affiliated agency of the author.

\section{References}

Brownson, J.V., 2013, Bible, gender, sexuality: Reframing the church's debate on same sex relationships, William B. Eerdmans Publishing Company, Grand Rapids, ML.

Countryman, L.W., 1988, Dirt, greed and sex: Sexual ethics in the New Testament and their implications for today, Fortress Press, Philadelphia, PA.

Crossan, J.D., 1991, The historical Jesus: The life of a Mediterranean Jewish peasant, HarperCollins Publishers, San Francisco, CA.

DeConick, A.D., 2003, 'The great mystery of marriage, sex and conception in ancient Valentinian traditions', Vigiliae Christianae 57(3), 307-342. https://doi. org/10.1163/157007203322204606

Deming, W., 2004, Paul on marriage and celibacy: The Hellenistic background of 1 Corinthians 7, 2nd edn., William B. Eerdmans Publishing Company, Grand Rapids, MI.

Duff, P.B., 2017, Jesus followers in the Roman Empire, William B. Eerdmans Publishing Company, Grand Rapids, MI.

Field, J.A., 1945, 'The purpose of the Lex Iulia et Papia Poppaea', The Classical Journal 40(7), 398-416, viewed 01 December 2020, from http://www.jstor.org/ stable/3292043.
Gereformeerde Kerke in Suid-Afrika (GKSA), 2015, Kerkordeboekie van die Gereformeerde Kerke in Suid-Afrika, CJBF, Potchefstroom.

Horsley, R.A., 1993, Jesus and the spiral of violence: Popular Jewish resistance in Roman Palestine, Harper \& Row, San Francisco, CA.

Hunter, D.G. (ed.), 2018, Marriage and sexuality in early Christianity, Fortress Press, Minneapolis, MN.

Ignatius, 2003, The Apostolic Fathers, Vol. 1: I Clement, II Clement, Ignatius, Polycarp, Didache, Loeb Classical Library 24, transl. B.D. Ehrman, Harvard University Press, Cambridge and Ignatius (35-140 CE; see Ign. Pol. 5:1-2 [Ehrman, LCL]).

Instone-Brewer, D., 2002, Divorce and remarriage in the Bible: The social and literary context, William B. Eerdmans Publishing Company, Grand Rapids, MI.

Janse van Rensburg, A., 2020, 'Moreletapark: "Gooi sinode toe met besware", Netwerk24, viewed 26 March 2020, from https://www.netwerk24.com/Nuus/ Algemeen/moreletapark-gooi-sinode-toe-met-besware-20200226.

Kelly, J.N.K., 1998, Jerome: His life, writings and controversies, Duckworth, London.

Kloppenborg, J.S., 1990, 'Alms, debt, and divorce: Jesus' ethics in their Mediterranean context', Toronto Journal of Theology 6(2), 182-200. https://doi.org/10.3138/ tjt.6.2.182

Köstenberger, A., 2003, 'Marriage and family in the New Testament', in K.M. Campbell (ed.), Marriage and family in the biblical world, pp. 240-284, InterVarsity Press, Downers Grove, IL.

Loader, W., 2004, The Septuagint, sexuality, and the New Testament: Case studies on the impact of the LXX in Philo and the New Testament., William B. Eerdmans Publishing Company, Grand Rapids, MI.

Loader, W., 2005, Sexuality and the Jesus tradition, William B. Eerdmans Publishing Company, Grand Rapids, MI.

Loader, W., 2012, The New Testament on sexuality, William B. Eerdmans Publishing Company, Grand Rapids, MI.

Loader, W., 2013, Making sense of sex: Attitudes towards sexuality in early Jewish and Christian literature, William B. Eerdmans Publishing Company, Grand Rapids, MI.

Malina, B.J., 1981, The New Testament world: Insights from cultural anthropology, Westminster John Knox Press, Louisville, KY.

Malina, B.J. \& Neyrey, J.H., 1991, 'Honor and shame in Luke-Acts: Pivotal values of the Mediterranean world', in J.H. Neyrey (ed.), The social world of Luke-Acts: Models for interpretation, pp. 25-65, Hendrickson Publishers, Inc, Peabody, MA.

Malina, B.J. \& Rohrbaugh, R.L., 2003, Social-science commentary on the Synoptic gospels, 2nd edn., Fortress Press, Minneapolis, MN.

Martin, D.B., 2006, Sex and the single savior: Gender and sexuality in biblical interpretation, Westminster John Knox Press, Louisville, KY.

Meier, J.P., 1991, A marginal Jew - Rethinking the historical Jesus: The roots of the problem and the person, vol. 1, Doubleday, New York, NY.

Methodist Church of Southern Africa, 2016, The Methodist book of order: The laws and discipline of the Methodist Church of Southern Africa, 12th edn., Methodist Publishing House, Cape Town.

Nederduitse Gereformeerde Kerk (NGK), 2015, Die Kerkorde van die Nederduitse Gereformeerde Kerk met reglemente, beleid, funksionele besluite en riglyne, en tussen-orde soos vasgestel deur die Algemene Sinode in Oktober 2015, Bybelmedia, Wellington.

Nederduitsch Hervormde Kerk van Afrika (NHKA), 2016, Kerkorde van die Nederduitsch Hervormde Kerk van Afrika, Pretoria.

Nederduitsch Hervormde Kerk van Afrika (NHKA), 2019, Agenda van die 72ste Algemene Kerkvergadering.

New Advent, n.d., Church Fathers: Against Heresies (St. Irenaeus), viewed 23 August 2020, from https://www.newadvent.org/fathers/0103.htm.

New Advent, n.d., Church Fathers: Against Marcion (Tertullian), viewed 23 August 2020, from https://www.newadvent.org/fathers/0312.htm.

New Apostolic Church International, n.d., Marriage as a divine institution, viewed 26 March 2020, from http://www.nak.org/catechism/13-new-apostolicchristians-and-their-life-of-faith/133-marriage-and-family/1331-marriage-as-adivine-institution/.

Neyrey, J.H., 1993a, 'Dyadism', in B.J., Malina \& J.J. Pilch (eds.), Biblical social values and their meaning: $A$ handbook, pp. 49-52, Hendrickson Publishers, Peabody.

Neyrey, J.H., 1993b, 'Group orientation', in B.J. Malina \& J.J. Pilch (eds.), Biblical social values and their meaning: A handbook, pp. 88-91.

Neyrey, J.H., 2004, Render to God: New Testament understandings of the divine, Fortress Press, Minneapolis, MN

Osiek, C., 2006, 'The New Testament teaching on family matters', Hervormde Teologiese Studies 62(3), 819-843. https://doi.org/10.4102/hts.v62i3.382

Pilch, J., 1993, "Beat his ribs while he is young" (Sir 30:12): A window on the Mediterranean world', Biblical Theology Bulletin: Journal of Bible and Culture 23(3), 101-113. https://doi.org/10.1177/014610799302300303

Rohrbaugh, R.L., 2006, 'Hermeneutics as cross-cultural encounter: Obstacles to understanding', HTS Teologiese Studies/Theological Studies 62(2), 559-576. https://doi.org/10.4102/hts.v62i2.365

Schüssler Fiorenza, E., 1982, 'Discipleship and patriarchy: Early Christian ethos and Christian ethics in a feminist theological perspective', in L. Rasmussen (ed.), The annual of the society of Christian ethics: Selected papers, pp. 131-172, Council of the Study of Religion, Waterloo. 
Severy-Hoven, B., 2012a, 'Marriage legislation of Augustus', The Encyclopedia of Ancient History, viewed 07 April 2020, from https://onlinelibrary.wiley.com/doi/ abs/10.1002/9781444338386.wbeah22188.

Severy-Hoven, B., 2012b, 'Lex lulia and lex Papia', in The Encyclopedia of Ancient History, viewed 07 April 2020, from https://onlinelibrary.wiley.com/doi/10.1002/ 9781444338386.wbeah13167.

The Apostolic Faith: Earnestly Contend for the Faith, 2017, The sanctity of marriage viewed 26 March 2020, from http://apostolicfaith.org/online-magazine/7727511 4785439thesanctityofmarriage.

Uniting Presbyterian Church in Southern Africa, 2013, Statement on marriage, viewed 26 March 2020, from https://unitingpresbyterian.org/web/wp-content/uploads/ 2013/09/statement on marriage.pdf.
Van Eck, E., 1995, Galilee and Jerusalem in Mark's story of Jesus: A narratological and social-scientific reading, Kital, Pretoria.

Van Eck, E., 2007a, 'Die huwelik in die eerste-eeuse Mediterreense wêreld (II): Huwelik, egbreuk, egskeiding en hertrou', Hervormde Teologiese Studies 63(1), 103-128. https://doi.org/10.4102/hts.v63i1.205

Van Eck, E., 2007b, 'Die huwelik in die eerste-eeuse Mediterreense wêreld (I): Vroue in 'n man se wêreld', HTS Teologiese Studies/Theological Studies 63(1), 81-101.

Van Eck, E., 2007c, 'Die huwelik in die eerste-eeuse Mediterreense wêreld (III): Jesus en die huwelik', HTS Teologiese Studies/Theological Studies 63(2), 481-513.

Vardy, P., 2009, The puzzle of sex, SCM Press, London.

Wheeler-Reed, D. 2017, Regulating sex in the Roman Empire: Ideology, the Bible, and the early Christians, Yale University Press, New Haven, CT. 